\title{
Aerobic Degradation of 4-Monobrominated Diphenyl Ether: Identifying and Characterizing Three Strains Isolated from Populus tomentosa Phyllosphere
}

\author{
Xinwei Zhao, Ming Liu, Yuchao Liu, Yuling Li, Shuang Zhang, Kejiu Du* \\ College of Forestry, Agricultural University of Hebei, Baoding 071000, China, \\ Hebei Provincial Key Laboratory of Tree Species Germplasm Resources and Forest Protection, \\ Baoding 071000, China
}

Received: 31 October 2016

Accepted: 29 December 2016

\begin{abstract}
Three strains, designated A1, B2, and C3, capable of aerobic degradation of 4-monobrominated diphenyl ether (4-BDE) as sole carbon and energy source were originally isolated from Populus tomentosa phyllosphere. The three strains were identified as Sphingomonas, Enterobacteria, and Curtobacterium based on their morphology and molecular properties. The 4-BDE concentration gradient was set up and showed that the three strains could still survive at $500 \mathrm{mg} \mathrm{L}^{-1}$ 4-BDE. Their removal efficiencies were detected by utilizing GC- $\mu \mathrm{ECD}$ and the analysis showed that $\mathrm{A} 1, \mathrm{~B} 2$, and $\mathrm{C} 3$ were able to transform $33 \%, 20 \%$, and $17 \%$ of $80 \mathrm{mg} \mathrm{L}^{-1} 4-\mathrm{BDE}$ in $2 \mathrm{~d}$ incubation, respectively. This is the first report of aerobic degradation of 4-BDE by three bacterial strains isolated from phyllosphere.
\end{abstract}

Keywords: 4-BDE, Populus tomentosa, phyllosphere, aerobic degradation

\section{Introduction}

Polybrominated diphenyl ethers (PBDEs) are a class of synthetic organic compounds consisting of 209 congeners, while the deca-, octa-, and pentabromodiphenyl ethers are most commercially used. As one kind of effective and economical flame retardant, PBDEs have been widely used in various products such as plastics, electronic appliances, furniture, and vehicles [1-2]. There is no chemical bind between PBDEs and materials, so PBDEs easily leak into the environment during the production,

*e-mail: dukejiu@126.com use, and disposal of consumer products. Now, however, PBDE congeners have been widely detected in soils, air, water, animals (even in the Arctic biosphere), and humans [3-6]. PBDEs have attracted growing concerns regarding their properties of persistence, bioaccumulation, and biotoxicity [7-9]. Even though the industrial production of some PBDEs is restricted under the Stockholm Convention, some PBDEs are still in production like decabromodiphenyl ether (BDE209). The lower brominated diphenyl ethers (average 1-6 bromine atoms per molecule), which can be formed from photochemical and biological degradation of high brominated congeners [10-14], may carry more toxicity and bioaccumulation $[10,15,16]$. Among the lower brominated congeners, the 
monobrominated diphenyl ethers have attracted extensive attention [17-21].

Biodegradation plays a vital role in the transformation and removal of detrimental organic chemicals. For biodegradation of PBDEs, microbial anaerobic and aerobic degradation are under study. Microbial anaerobic transformation has demonstrated that, in most cases, PBDEs were debrominated to less brominated congeners, but required a relatively long time $[11,22]$. Compared to anaerobic degradation, the advantages of microbial aerobic degradation on PBDEs are obvious: the degradation time cycle is shorter and the metabolites will not carry greater toxicity as the result of the characteristic degradation mechanism that PBDEs go through for hydroxylation and ring opening reaction [23-24].

The phyllosphere, aerial parts of plants dominated by the leaves, was regarded as supporting the most abundant colonizers on earth. Based on the vegetation model, the global leaf surface is as approximately vast as land surface if just one side of the leaf is in calculation [25-26]. The density of microorganisms residing on the phyllosphere (microbial epiphytes) is enormous, averaging $10^{6}-10^{7}$ bacteria per square $\mathrm{cm}$ on leaf surface, and the species are various [27-30]. In recent years, studies about microbial epiphytes removing gaseous chemical compounds including toluene, ethylbenzene, xylene, and phenol have become available [31-34].

In this paper, 4-BDE, a model for biodegradation of lower brominated diphenyl ether, was chosen to investigate the degradation performance of the screened bacterial strains isolated from the leaves of Populus tomentosa [22]. Through traditional isolation and 4-BDE screening, three strains were obtained from the leaves of Populus tomentosa and identified. The 4-BDE concentration gradient was designed to test strains' 4-BDE tolerance ability. Based on the growth curves established on mineral salt medium containing $80 \mathrm{mg} \mathrm{L}^{-1} 4-\mathrm{BDE}$, the three strains' 4-BDE removal efficiency was detected by a gas chromatograph (GC) coupled with a microelectron capture detector ( $\mu \mathrm{ECD}$ ) after $2 \mathrm{~d}$ incubation. In this paper, we tried to prove the existence of 4-BDEdegrading strains on Populus tomentosa phyllosphere and investigated the corresponding removal efficiency that could expand the traditional existence state of PBDE degrading strains as well as contribute to comprehensive phytoremediation.

\section{Materials and Methods}

\section{Chemicals and Culture Mediums}

4-BDE (4-bromodiphenyl ether, purity $>98 \%$ ) was purchased from Tokyo Kasei Kogyo Co., Ltd. (TCL) and diluted with alcohol to $80 \mathrm{mg} \mathrm{mL}^{-1}$ before use. All standards and solutions were stored hermetically in amber glass vials at $4^{\circ} \mathrm{C}$ until use. All other chemicals and reagents used in this experiment were of analytical reagent grade or better. Nutrient medium was used for strain isolation and cultivation, and its composition consisted of $\left(\mathrm{g} \mathrm{L}^{-1}\right)$ : peptone 10 , beef extract 3 , agar 18 , and $\mathrm{NaCl} 5$.

Liquid nutrient medium (LUM) was used for strain cultivation, and its composition consisted of $\left(\mathrm{g} \mathrm{L}^{-1}\right)$ : peptone 10 , beef extract $3, \mathrm{NaCl} 5$.

Mineral salt medium (MSM) was used as the degradation medium, and its composition consisted of (g L ${ }^{-1}$ ): $\mathrm{Na}_{2} \mathrm{HPO}_{4} 2.13, \mathrm{KH}_{2} \mathrm{PO}_{4} 1.30, \mathrm{NH}_{4} \mathrm{Cl} 0.50$, and $\mathrm{MgSO}_{4} \cdot 7 \mathrm{H}_{2} \mathrm{O} 0.20$.

The $\mathrm{PH}$ of culture medium was all adjusted to 7.3. The culture medium and containers were previously sealed and sterilized in an autoclave at $121^{\circ} \mathrm{C}$ for $20 \mathrm{~min}$.

\section{Strain Isolation}

Every three healthy leaves were cut from three individuals of Populus tomentosa. The target trees grow in the western campus of the Agricultural University of Hebei $\left(38^{\circ} 49^{\prime} 23.84^{\prime \prime} \mathrm{N}, 115^{\circ} 26^{\prime} 40.52^{\prime \prime} \mathrm{E}\right)$. The height of desired leaves was about $10 \mathrm{~m}$ above ground. The leaves were put in one sterile plastic bag once cut to avoid contrived contamination. In lab, the leaves were put upside down in a sterile $150 \mathrm{~mL}$ Erlenmeyer flask containing $80 \mathrm{~mL} \mathrm{MSM}$, and the leaf stalks were kept above the liquid level, then placed on a incubator shaker at $30^{\circ} \mathrm{C}$ and $150 \mathrm{rpm}$. Eight hours later, $20 \mathrm{ul}$ bacterium suspension was transferred to nutrient medium in clean bench and incubated the plate at $30^{\circ} \mathrm{C}$. Forty-eight hours later, single bacteria colonies were streaked on clean plates and repeated until they formed pure single colonies. All single colonies in $15 \%$ glycerinum were preserved at $-60^{\circ} \mathrm{C}$.

\section{Bacterial Activation}

To activate bacteria, the strains were cultivated in $100 \mathrm{~mL}$ Erlenmeyer flasks that contained $40 \mathrm{~mL}$ LUM. The initial culture turbidity of bacterium suspension was modulated to $\mathrm{OD}_{600}$ of 0.400 and incubated on a rotary shaker at $30^{\circ} \mathrm{C}$ and $150 \mathrm{rpm}$ for $24 \mathrm{~h}$. Then the biomass was harvested and separated from the LUM by centrifugation $\left(5,000 \mathrm{rpm}, 10 \mathrm{~min}, 4^{\circ} \mathrm{C}\right)$. The separated biomass was washed with MSM (5,000 rpm, $10 \mathrm{~min}$, $4^{\circ} \mathrm{C}$ ) three times and resuspended in MSM. In this study, prior to operations including bacterial screening, 4-BDE tolerance test, growth curve establishment, and removal detection, the activated bacterium suspension was prepared and modulated to 0.100 at $\mathrm{OD}_{600}$ and used within $2 \mathrm{~h}$. Besides that, the setting was $30^{\circ} \mathrm{C}$ and 150 rpm when a rotary shaker was needed and bacterium suspension containers were $100 \mathrm{~mL}$ Erlenmeyer flasks, except for section 2.6, which used $60 \mathrm{ml}$ tubes.

\section{Strain Screening}

We conducted strain screening to seek strains capable of metabolizing 4-BDE as the sole carbon and energy source. The screening containers contained 
$40 \mathrm{~mL}$ bacterium suspension with $20 \mathrm{mg} \mathrm{L}^{-1} 4$-BDE and was incubated on a rotary shaker. Every 24 h, $0.700 \mathrm{ml}$ bacterium suspension was taken out to measure the value of $\mathrm{OD}_{600}$ on a clean bench and put it back on a rotary shaker for subsequent measurement. The strain screening will be sustained for five days. The operation of $\mathrm{OD}_{600}$ value measurement was the same below. In this paper, all biological repeats were carried out in triplicate (including strain screening, tolerance test of strains on 4-BDE, growth curves establishment on MSM containing $80 \mathrm{mg}$ $\mathrm{L}^{-1} 4-\mathrm{BDE}$ and LUM, and 4-BDE removal detection).

\section{Identification of Bacterial Strain}

In addition to fundamental morphological and physiological characterizations, the 16S rDNA gene was amplified using the primer pair $27 \mathrm{~F}$ and $1492 \mathrm{R}$ [35]. Sequencing was performed after recycling and purification. 16S rDNA sequences of degrading strains were compared and aligned with sequences deposited in the GenBank database using the BLAST program.

\section{Tolerance Test of Strains on 4-BDE}

The pollutant concentration gradient was set as 40 , $80,120,160,200,300,400$, and $500 \mathrm{mg} \mathrm{L}^{-1}$. The $60 \mathrm{ml}$ tube containing $10 \mathrm{ml}$ bacterium suspension served as an incubation container. The parallel controls were set without the addition of 4-BDE. These incubation systems were cultivated on a rotary shaker. The value of $\mathrm{OD}_{600}$ was measured at intervals of $24 \mathrm{~h}$.

\section{Growth Curve Establishment on MSM Containing $80 \mathrm{mg} \mathrm{L}^{-1} 4-\mathrm{BDE}$ and LUM}

To investigate the growth dynamic of strains on different nutrition conditions, a growth curve establishment was conducted. In MSM, 4-BDE was added to the $40 \mathrm{ml}$ bacterium suspension with final concentration of $80 \mathrm{mg} \mathrm{L}^{-1}$. To further verify the 4-BDE function as the sole carbon and energy source, the same amount of 4-BDE was added to the incubation systems at $90 \mathrm{~h}$. In LUM, the initial $\mathrm{OD}_{600}$ value of the bacterial suspension was also adjusted to 0.100 . Place all incubation systems on a rotary shaker. $\mathrm{OD}_{600}$ value measurement was conducted at intervals of $6 \mathrm{~h}$ within the desired time.

\section{4-BDE Removal Detection}

Every incubation container containing $40 \mathrm{~mL}$ bacterium suspension with $80 \mathrm{mg} \mathrm{L}^{-1} 4$-BDE. Place the incubation systems on a rotary shaker. The parallel controls were set without the addition of bacterial biomass. After $48 \mathrm{~h}$ incubation, $10 \mathrm{~mL} \mathrm{n}$-hexane was added to each of the incubation systems and all systems were set on rotary shaker at $20^{\circ} \mathrm{C}$ and $150 \mathrm{rpm}$ for $30 \mathrm{~min}$. After shaking, $1 \mathrm{~mL}$ supernate was extracted from the suspensions. The removal efficiency was analyzed by gas chromatograph (Agilent Technologies 6890N) coupled with a micro-electron capture detector (Agilent Technologies, USA; GC- $\mu$ ECD). A high-performance capillary column (Agilent J\&W DE-5MS UI: $30 \mathrm{~m} \cdot 0.25 \mathrm{~mm}, 0.25 \mu \mathrm{m}$ film thickness) was used. For temperature setting, the oven temperature was initiated at $80^{\circ} \mathrm{C}$, ramped up $10^{\circ} \mathrm{C} / \mathrm{min}$ to $180^{\circ} \mathrm{C}, 4^{\circ} \mathrm{C} / \mathrm{min}$ to $250^{\circ} \mathrm{C}$, and then up to $300^{\circ} \mathrm{C}$ at $5^{\circ} \mathrm{C} / \mathrm{min}$, and held for $3 \mathrm{~min}$. Automatic injection of $1 \mu \mathrm{L}$ sample was conducted in the splitless mode. Chromatographicgrade helium was used as the carrier gas at a flow rate of $1.1 \mathrm{~mL} \mathrm{~min}^{-1}$. The injector temperature was fixed at $220^{\circ} \mathrm{C}$ and the ECD was maintained at $280^{\circ} \mathrm{C}$.

\section{Statistical Methods}

In statistical analysis process, Origin 8.5 was performed to calculate the mean value and standard deviation (SD) for three replicates and form figures. Specifically, the 4-BDE removal efficiency was first calculated the removal efficiency for each replicate and then we calculated the mean value and SD for three replicates by Origin 8.5.

\section{Results and Discussion}

\section{The Screening and Identification of the 4-BDE} Degrading Strains

After three times sampling we obtained three aerobic strains capable of utilizing 4-BDE as sole carbon and energy source. The strains were designated A1, B2, and $\mathrm{C} 3$ in time sequence. Colonies of strain $\mathrm{A} 1$ on the nutrient medium showed a white pigmentation without mucus, B2 showed white pigmentation with mucus, and C3 showed pink pigmentation with mucus. For gram staining, strains $\mathrm{A} 1, \mathrm{~B} 2$, and $\mathrm{C} 3$ were Gram negative, negative, and positive, respectively. The $16 \mathrm{~S}$ rDNA analysis revealed that strains A1, B2, and C3 exhibit the highest sequence similarity with Sphingomonas echinoides strain NRRL B-3127 (KP208156.1, 99\% homology), Enterobacter sp. SJZ-5 (LC014954.1, 94\% homology), and Curtobacterium sp. MR MD2014 (KU740254.1, 99\% homology) according to blast search using the NCBI Genbank. Through elementary identification, strains A1, B2, and C3 were identified as genus Sphingomonas sp., Enterobacter sp., and Curtobacterium sp. The phylogentic trees of A1, B2, and C3 were generated by MEGA5 and were described in Figs 1(a-c). The phylogentic trees were constructed by the amplified 16S rRNA sequence fragments of A1, B2, and $\mathrm{C} 3$, and their neighbors in GenBank via BLAST (the statistical method: neighbor-joining; bootstrap method: 1,000 re-samplings; scale bar: percent similarity; number in parentheses: accession number).

\section{The 4-BDE Tolerance Test}

The growth dynamic curves of three strains on 4-BDE gradient concentration were shown in Figs 2(a-c), which show that the biomass of the parallel controls showed 


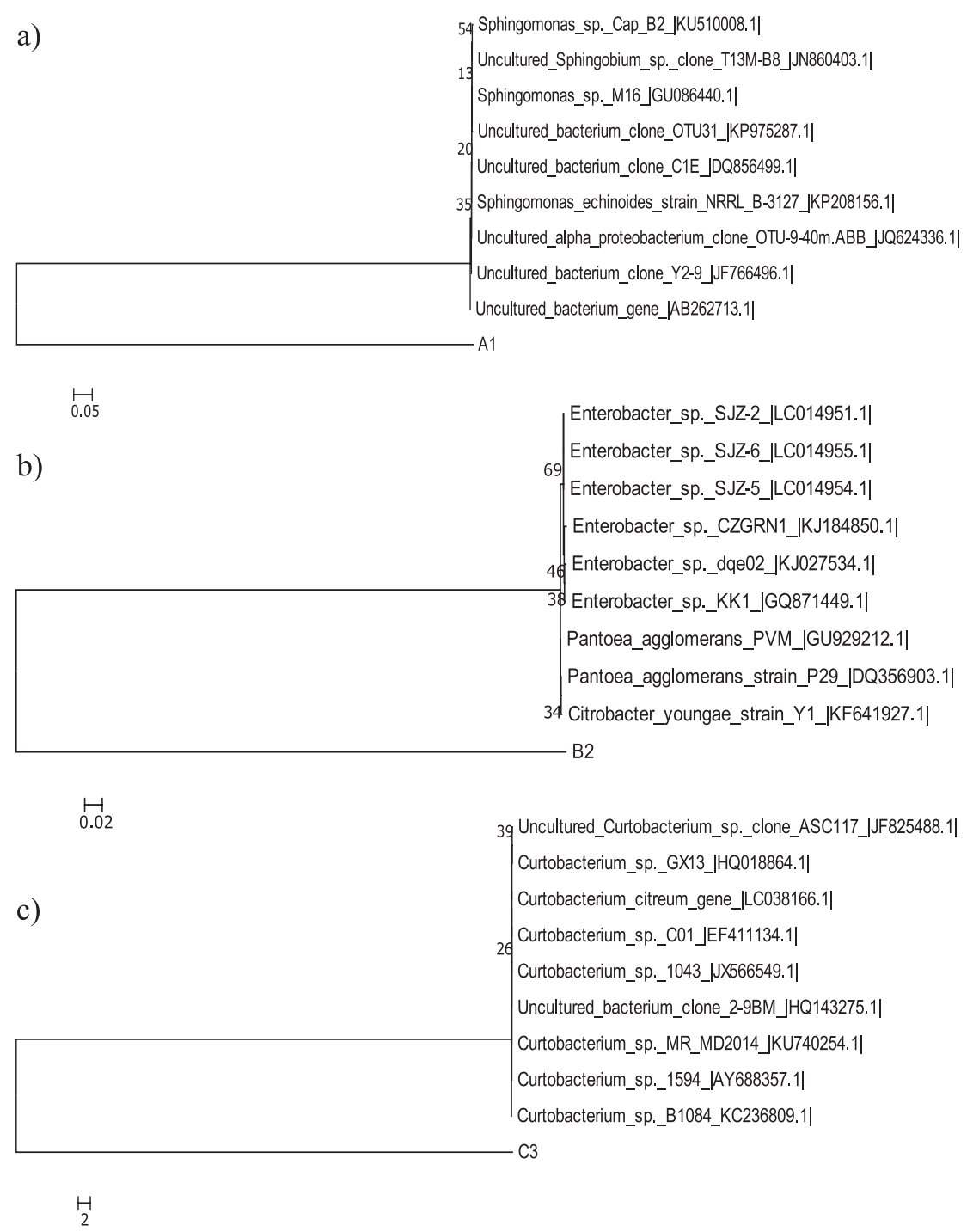

Fig. 1. The phylogentic trees of strains: a) A1, b) B2, c) C3

significant decline within 6d. In Fig. 2a), Al's biomass in high 4-BDE concentration $\left(300,400\right.$, and $\left.500 \mathrm{mg} \mathrm{L}^{-1}\right)$ is lower than low 4-BDE concentration within the first $2 \mathrm{~d}$. After 3d, the incubation systems under $200 \mathrm{mg} \mathrm{L}^{-1}$ 4-BDE stepped into stationary phase but concentration over $200 \mathrm{mg} \mathrm{L}^{-1}$ emerged with a strong upward trend to a different extent. Different from A1, B2 showed no temporal biomass overlap as depicted in Fig. 2b). Earlier than A1, all incubation systems of B2 stepped into stationary or decline phase after 2d. In Fig. 2c), in spite of the 4-BDE concentration difference, all culture turbidity of $\mathrm{C} 3$ was in the range of $0.15 \sim 0.20$ at $\mathrm{OD}_{600}$ within the 1d, except for the $40 \mathrm{mg} \mathrm{L}^{-1}$ group.

Taking the three strains' growth conditions into account, we found that more biomass yield was produced along with the 4-BDE concentration increase. Among the three strains, A1 showed the most powerful degradation ability. Another difference is that at high 4-BDE concentration, the culture turbidity of B2 and C3 declined after $3 \mathrm{~d}$, but A1 still showed a strong upward trend. For the highest culture turbidity at $500 \mathrm{mg} \mathrm{L}^{-1}$
4-BDE, A1, B2, and C3 reached about 0.48 at $6 \mathrm{~d}, 0.414$ at $2 \mathrm{~d}$, and 0.363 at $3 \mathrm{~d}$, respectively (at $\mathrm{OD}_{600}$ ). Actually, the aqueous solubility of monobrominated diphenyl ethers ranges from 1 to $10 \mathrm{mg} \mathrm{L}^{-1}$, and the positive correlation of biomass yield to 4-BDE concentration may reveal that the 4-BDE unsolvable in the bacterium suspension can also be utilized.

\section{Growth Curve Establishment on LUM and MSM Containing 4-BDE}

In Fig. 3a), strain A1 showed the most powerful multiplication capacity in LUM, followed by B2 and C3, which reached the highest culture turbidity at $36 \mathrm{~h}$ of $1.048,24 \mathrm{~h}$ of 0.757 , and $54 \mathrm{~h}$ of 0.629 , respectively (at $\left.\mathrm{OD}_{600}\right)$. At $36 \mathrm{~h}$, strains $\mathrm{A} 1$ and $\mathrm{C} 3$ stepped on stationary phases and strain B2 did at $12 \mathrm{~h}$.

Fig. 3b) exhibited the growth curves of three strains in MSM containing 4-BDE for $120 \mathrm{~h}$. At first, 4-BDE was added to incubation systems at the concentration of $80 \mathrm{mg} / \mathrm{L}$ and at $90 \mathrm{~h}$. To further verify 4-BDE's role as 
a)

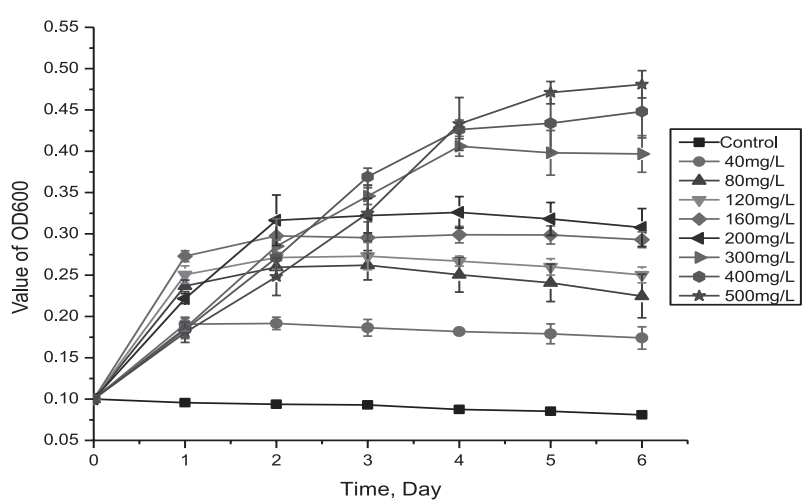

b)

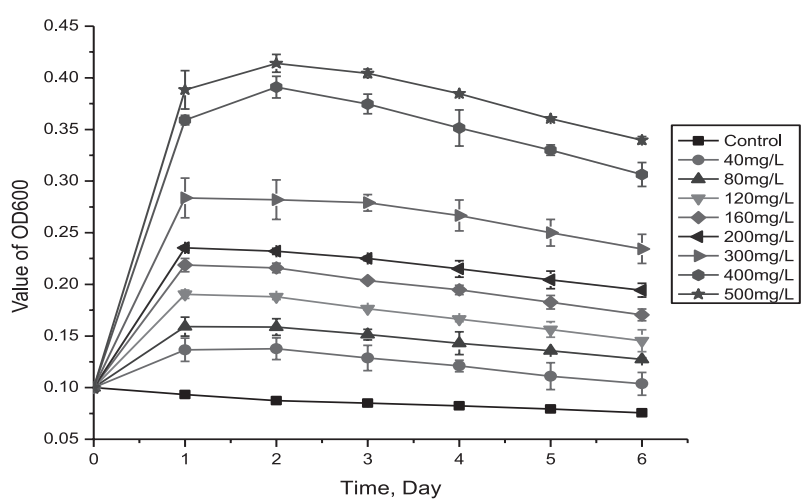

c)

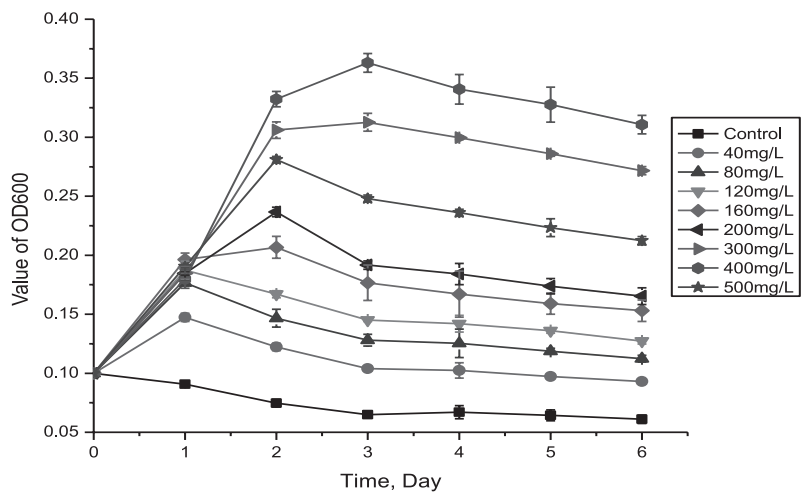

Fig. 2. Growth dynamic curves on 4-BDE gradient concentration strain: a) A1, b) B2, c) C3.

sole carbon and energy source, the same amount of 4-BDE was added to incubation systems again. From Fig. 3b), It can be seen that three strains were in the lag phase in the first $6 \mathrm{~h}$. The growth trend of three strains in the MSM containing 4-BDE was similar in LUM. After the second 4-BDE addition, the culture turbidity of all incubation systems went up significantly upon the addition without lag phase and from this result it can be expected that the 4-BDE dose acts as the sole carbon and energy source. Compared to the first $6 \mathrm{~h}$, no appearance of lag phase after the second addition may signify that the strains had been adaptable to the 4-BDE aqueous environment. Besides, two differences can be seen from Fig. 3b): less biomass yield and earlier arrival on stationary phase compared to the first 4-BDE addition.

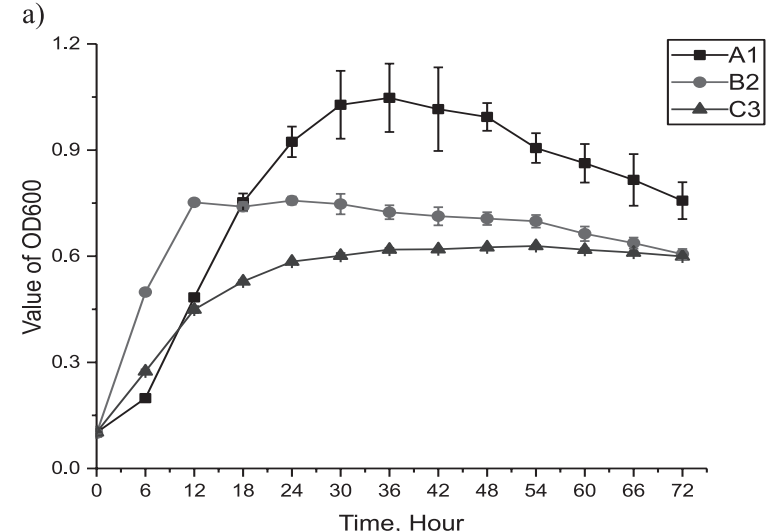

b)

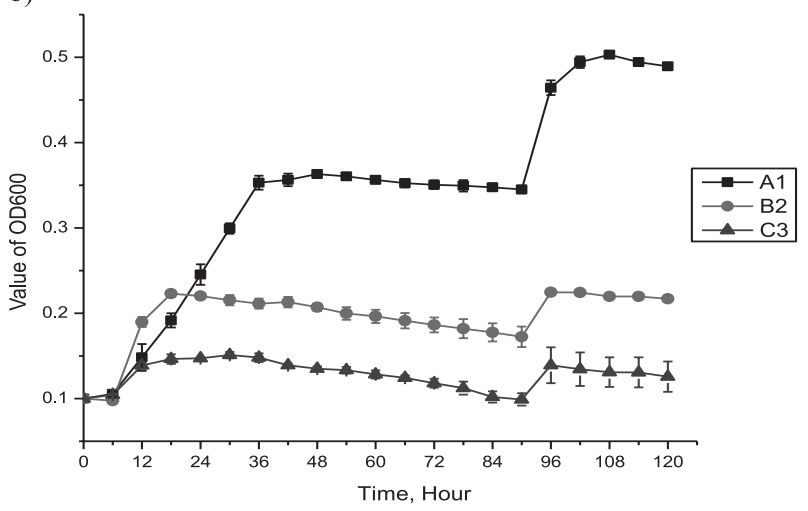

Fig. 3. Growth curves of three strains: a) on liquid nutrition medium (LUM), b) in MSM containing $80 \mathrm{mg} \mathrm{L}^{-1} 4-\mathrm{BDE}$ and with the same amount of 4-BDE addition at $90 \mathrm{~h}$.

\section{4-BDE Removal Efficiency}

After $48 \mathrm{~h}$ incubation, the 4-BDE removal efficiency was shown in Table 1 and the result showed that $33 \%$, $20 \%$, and $17 \%$ of $80 \mathrm{mg} \mathrm{L}^{-1} 4$-BDE was transformed by $\mathrm{A} 1, \mathrm{~B} 2$, and C3. Removal efficiency was the positive relationship to the growth curves of three strains on LUM and $80 \mathrm{mg} \mathrm{L}^{-1}$ 4-BDE MSM. In parallel control, no significant 4-BDE removal occurred within the same time, implicating that possible volatilization or non-biological degradation was negligible. For 4-BDE biodegradation, the three strains isolated from the phyllosphere have at least three advantages.

First, 4-BDE can be the sole source of carbon and energy for the three strains, which means no growth substrate or co-metabolism substrate was necessary. Lysinibacillus fusiformis strain DB-1 can transform deca$\mathrm{BDE}$ to lower brominated BDEs in aerobic conditions under the premise of using lactate, pyruvate, or acetate as carbon sources [36]. Sphingomonas sp. PH-07 could transform five selected PBDEs by using diphenyl ether as a carbon source [37]. For further application of microbial degradation on halogenated hydrocarbon pollutants, the carbon source addition would increase the economic burden of remediation and may worsen environment pollution if the carbon source itself is toxic.

Second, the 4-BDE removal efficiency of three strains $-33 \%$ for $\mathrm{A} 1,20 \%$ for $\mathrm{B} 2$, and $17 \%$ for $\mathrm{C} 3$ in 
Table 1. Removal efficiency of strains A1, B2, and C3 on $80 \mathrm{mg} \mathrm{L}^{-1} 4$-BDE after $48 \mathrm{~h}$.

\begin{tabular}{|c|c|c|c|}
\hline \multirow{2}{*}{ Duration(h) } & \multicolumn{3}{|c|}{ Percent removal $^{\mathrm{a}}(\%)$} \\
\cline { 2 - 4 } & A1 & B2 & C3 \\
\hline 48 & $33.65 \pm 8.39$ & $20.44 \pm 3.02$ & $17.14 \pm 0.24$ \\
\hline
\end{tabular}

${ }^{a}$ Values shown are mean \pm SD for three replicates

$2 \mathrm{~d}$ incubation - was comparable or superior to most 4-BDE anaerobic and aerobic microbial or community removal efficiencies if taking into consideration the initial bacterium suspension optical density of 0.100 and the initial 4-BDE concentration of $80 \mathrm{mg} / \mathrm{L}$. For example, Rhodococcus sp. RR1 could aerobically transform $20 \%$ of $17 \mathrm{ug} \mathrm{L}^{-1}$ mono- and di-BDE within three days [23]. Sphingomonas sp. PH-07 could aerobically degrade $23 \%$ of mono-BDE or $14 \%$ di-BDE within eight days with biphenyl ether addition, and the pollutant concentration was fairly high at $1 \mathrm{~g} / \mathrm{L}$ [37]. Recently, Pseudomonas putida, an aromatics-degrading strain, was used for the aerobic biodegradation of 4-BDE, and the degradation efficiency of $2 \mathrm{mg} / \mathrm{L} 4-\mathrm{BDE}$ was $42.5 \%$ after $10 \mathrm{~d}$ treatment [38]. Two anaerobic sludge samples, which were obtained from the anaerobic tanks in two wastewater treatment facilities, were employed for 4-BDE degradation and after incubation by $5 \mathrm{mgL}^{-1} 4$-BDE for 16 days, about $77 \%$ of 4-BDE was degraded by Li-Ming sludge and $31 \%$ of 4-BDE was degraded by Jhongsing sludge [22].

Third, different from the degrading strains isolated from the pollutant-contaminated soil, sewage treatment plant or places with contamination history [36, 37, 39-40], the three strains were from the green and healthy Populus tomentosa phyllosphere, which means strains capable of degrading PBDEs are not exclusive to bacteria surviving in a heavily contaminated environment. For future phytoremediation which contains (but is not limited to) plant bodies and related microbial epiphytes, the original degrading strains from microbial epiphytes have one huge advantage: they have been a part of the bacterial community on the phyllosphere and they have adapted to the leaf surface environment. But for the addition of degrading strains (even possessing better degradation efficiency) which are isolated from other biotic districts to the phyllosphere, the introduced degrading strains may not survive or degrade pollutants on the leaf surface as there maybe not niches for them. And it has been proven that Sphingomonas sp., a versatile degrading genus and Al's genus, is widely distributed in some plants' phyllospheres [41-43].

As a class of semi-volatile organic compounds (SVOCs), the fastest way to spread regionally and globally for PBDEs is through the atmosphere [44]. The existing state of bromominated biphenyl ethers in air can be gaseous or adherency to fine particulate matters, and both can migrate for long distances [45-47]. It has been reported that gaseous pollutants are prone to accumulate on the leaf surface, several to dozens of times higher than in the air, which is favorable to be accessible to and degraded by microbial epiphytes [33]. But the degradation experiment conducted in this paper was in the aqueous phase, so the degrading strain was symmetrical, which is different from the bacterial aggregates in phyllosphere aboriginality [48]. Additionally, the 4-BDE concentration performed in this study was definitely higher compared to environmental air [49-50]. So for further research it is necessary to investigate the removal effect of gaseous PBDEs as well as PBDEs absorbed on particulate matter by microbial epiphytes at a larger scale and in situ.

\section{Conclusions}

Form Populus tomentosa phyllosphere, we obtained three bacterial strains (A1, B2, and $\mathrm{C} 3$ ) that are able to utilize 4-bromodiphenyl ether (4-BDE) as the sole carbon and energy source. Based on the elementary morphology and molecular properties, the three strains are identified as Sphingomonas, Enterobacteria, and Curtobacterium, respectively. To test 4-BDE tolerance property, we set up a concentration gradient and the result showed that $500 \mathrm{mg} \mathrm{L}^{-1} 4-\mathrm{BDE}$ in MSM is not the tolerance limit point for three strains. By utilizing GC- $\mu \mathrm{ECD}$, removal efficiency was analyzed. A1, B2, and $\mathrm{C} 3$ were able to transform $33 \%, 20 \%$, and $17 \%$ of $80 \mathrm{mgL}^{-1} 4-\mathrm{BDE}$ in $2 \mathrm{~d}$ incubation. This is the first report of PBDE biodegradation by microbial epiphytes, which will expand the existing field of PBDE degrading strains. We expect that the result of the experiment will promote the PBDE microbial epiphytes degradation in situ and benefit integrated phytoremediation.

\section{Acknowledgements}

This work was supported by the National High Technology Research and Development Program of China (2012AA101403), the State Key Laboratory of Environmental Chemistry and Ecotoxicology (KF200903), and the National Natural Science Foundation of China (30972384).

\section{References}

1. SONG W., FORD J.C., LI A., STURCHIO N.C., ROCKNE K., BUCKLEY D.R., MILLS W.J. Polybrominated diphenyl ethers in the sediments of the Great Lakes. 3. Lakes Ontario and Erie. Environ Sci Technol, 39 (15), 5600, 2005.

2. LEUNG A.O.W., LUKSEMBURG W.J., WONG A.S., WONG M.H. Spatial distribution of polybrominated diphenyl ethers and polychlorinated dibenzo-p-dioxins and dibenzofurans in soil and combusted residue at Guiyu, an electronic waste recycling site in southeast China. Environ Sci Technol, 41 (7), 2730, 2007.

3. HITES R.A. Polybrominated diphenyl ethers in the environment and in people: a meta-analysis of concentrations. Environ Sci Technol. 38 (4), 945, 2004. 
4. MAI B., CHEN S., LUO X., CHEN L., YANG Q., SHENG G., PENG P., FU J., ZENG E.Y. Distribution of polybrominated diphenyl ethers in sediments of the pearl river delta and adjacent south china sea. Environ Sci Technol. 39 (10), 3521, 2005

5. HUNG H., KALLENBORN R., BREIVIK K., SU Y., BRORSTRÖM-LUNDÉN E., OLAFSDOTTIR K., THORLACIUS J.M., LEPPÄNEN S., BOSSI R., SKOV H., MANØ S., PATTON G.W., STERN G., SVERKO E., FELLIN P. Atmospheric monitoring of organic pollutants in the arctic under the arctic monitoring and assessment programme (AMAP): 1993-2006. Sci Total Environ. 408 (15), 2854, 2010.

6. SU Y., HUNG H., SVERKO E., FELLIN P., LI H. Multiyear measurements of polybrominated diphenyl ethers (PBDEs) in the Arctic atmosphere. Atmos Environ. 41 (38), 8725, 2007.

7. DOMINGO J.L. Polybrominated diphenyl ethers in food and human dietary exposure: a review of the recent scientific literature. Food Chem Toxicol. 50 (2), 238, 2012.

8. ESKENAZI B., CHEVRIER J., RAUCH S.A., KOGUT K., HARLEY K.G., JOHNSON C., TRUJILLO C., SJÖDIN A., BRADMAN A. In utero and childhood polybrominated diphenyl ether (PBDE) exposures and neurodevelopment in the CHAMACOS study. Environ Health Persp. 121 (2), 257, 2013.

9. HAFFNER D., SCHECTER A. Persistent organic pollutants (POPs): a primer for practicing clinicians. Curr Environ Health Rep. 1 (2), 123, 2014.

10. ERIKSSON J., GREEN N., MARSH G., BERGMAN A. Photochemical decomposition of 15 polybrominated diphenyl ether congeners in methanol/water. Environ Sci Tech. 38 (11), 3119, 2004.

11. GERECKE A.C., HARTMANN P.C., HEEB N. V., KOHLER H.E., GIGER W., SCHMID P., ZENNEGG M., KOHLER M. Anaerobic degradation of decabromodiphenyl ether. Environ Sci Tech. 39 (4), 1078, 2005.

12. HE J., ROBROCK K.R., ALVAREZ-COHEN L. Microbial reductive debromination of polybrominated diphenyl ethers (PBDEs). Environm Sci Tech. 40 (14), 4429, 2006.

13. STAPLETON H.M., DODDER N.G. Photodegradation of decabromodiphenyl ether in house dust by natural sunlight. Environ Toxicol Chem. 272, 306, 2008.

14. TOKARZ J.A., AHN M., LENG J., FILLEY T.R., NIES L. Reductive debromination of polybrominated diphenyl ethers in anaerobic sediment and a biomimetic system. Environ Sci Tech. 42 (4), 1157, 2008.

15. VONDERHEIDE A.P., MUELLER K.E., MEIJA J., WELSH G.L. Polybrominated diphenyl ethers: Causes for concern and knowledge gaps regarding environmental distribution, fate and toxicity. Sci Total Environ. 400 (1-3), 425, 2008.

16. QIU X.H., MERCADO-FELICIANO M., BIGSBY R.M., HITES R.A. Measurement of polybrominated diphenyl ethers and metabolites in mouse plasma after exposure to a commercial pentabromodiphenyl ether mixture. Environ Health Perspect. 115 (7), 1052, 2007.

17. KEUM Y.S., LI Q.X. Reductive debromination of polybrominated diphenyl ethers by zerovalent iron. Environ Sci Technol. 39 (7), 2280, 2005.

18. FANG L., HUANG J., YU G., WANG L.N. Photochemichlal degradation of six polybrominated diphenyl ether congeners under ultraviolet irradiation in hexane. Chemosphere. 71 (2), $258,2008$.

19. CHEN S.J., TIAN M., LUO Y., LIN Z., LUO X.J., MAI B.X. Vertical profile of polybrominated diphenyl ethers
(PBDEs) in sediment from an e-waste area in south china. Environmental Science (Article in Chinese). 31(12), 3088, 2010.

20. HELLEDAY T., TUOMINEN K.L., ÅKE BERGMAN., JENSSEN D. Brominated flame retardants induce intragenic recombination in mammalian cells. Mutat Res. 439 (2), 137, 1999.

21. CAI M., LI Y., LI Y., DU K. Physiological and biochemical responses and microscopic structure changes of Populus tomentosa Carr seedlings to 4-BDE exposure. Environ Sci Pollut Res. 22 (18), 14258, 2015.

22. SHIH Y.H., CHOU H.L., PENG Y.H. Microbial degradation of 4-monobrominated diphenyl ether with anaerobic sludge. J Hazard Mater. 213-214 (2), 341, 2012.

23. ROBROCK K.R., COELHAN M., SEDLAK D.L., ALVAREZCOHEN L. Aerobic biotransformation of polybrominated diphenyl ethers (PBDEs) by bacterial isolates. Environ Sci Technol. 43 (15), 5705, 2009.

24. SHI G.Y., YIN H., YE J.S., PENG H., LI J., LUO C.L. Aerobic biotransformation of decabromodiphenyl ether (PBDE-209) by Pseudomonas aeruginosa. Chemosphere. 93 (8), 1487, 2013.

25. RUINEN J. Occurrence of Beijerinckia species in the phyllosphere. Nature. 177 (4501), 220, 1956.

26. WOODWARD F.I., LOMAS M.R. Vegetation dynamicssimulating responses to climatic change. Biol. Rev. 79 (3), 643, 2004.

27. LINDOW S.E., BRANDL M.T. Microbiology of the phyllosphere. Appl Environ Microbiol. 69 (4), 1875, 2003.

28. HALPERN M., RAATS D., LEV-YADUN S. Plant biological warfare: Thorns inject pathogenic bacteria into herbivores. Environ Microbiol. 9 (3), 584, 2007.

29. REDFORD A.J., BOWERS R.M., KNIGHT R., LINHART Y., FIERER N. The ecology of the phyllosphere: geographic and phylogenetic variability in the distribution of bacteria on tree leaves. Environ Microbiol. 12 (11), 2885, 2010.

30. IDO IZHAKI, SVETLANA FRIDMAN, YORAM GERCHMAN, MALKA HALPERN. Variability of Bacterial Community Composition on Leaves Between and Within Plant Species. Curr Microbiol. 66 (3), 227, 2013.

31. DARLINGTON A.B., DAT J.F., DIXON M.A. The biofiltration of indoor air: air flux and temperature influences the removal of toluene, ethylbenzene, and xylene. Environ. Sci. Technol. 35 (1), 240, 2001.

32. KEMPENEER L.D., SERCU B., VANBRABANT W., LANGENHOVE H. V., VERSTRAETE W. Bioaugmentation of the phyllosphere for the removal of toluene from indoor air. Appl. Microbiol. Biotechnol. 64 (2), 284, 2004.

33. SANDHU A., HALVERSON L.J., BEATTIE G.A. Bacterial degradation of airborne phenol in the phyllosphere. Environ Microbiol. 9 (2), 383, 2007.

34. KAWAGUCHI K., YURIMOTO H., OKU M., SAKAI Y. Yeast methylotrophy and autophagy in a methanol oscillating environment on growing Arabidopsis thaliana leaves. PLoS ONE. 6(9), 25257, 2011.

35. LANE D.J. 16S/23S rRNA sequencing. Nucleic acid techniques in bacterial systematics. New York, Wiley, 115, 1991.

36. DENG D., GUO J., SUN G., CHEN X., QIU M., XU M. Aerobic debromination of deca-BDE: isolation and characterization of an indigenous isolate from a PBDE contaminated sediment. Int Biodeter Biodegr. 65 (3), 465, 2011.

37. KIM Y.M., NAM I.H., MURUGESAN K., SCHMIDT S., CROWLEY D.E., CHANG Y.S. Biodegradation of diphenyl ether and transformation of selected brominated 
congeners by sphingomonas, sp. PH-07. Appl Microbiol Biotechnol. 77 (1), 187, 2007.

38. LV Y., LI L., CHEN Y., TANG Z., HU Y. Effects of glucose and biphenyl on aerobic cometabolism of polybrominated diphenyl ethers by pseudomonas putida: kinetics and degradation mechanism. Int Biodeter Biodegr. 108, 76, 2016.

39. ZHANG S., XIA X., XIA N., WU S., GAO F., ZHOU W. Identification and biodegradation efficiency of a newly isolated 2,2',4,4'-tetrabromodiphenyl ether (BDE-47) aerobic degrading bacterial strain. Int Biodeter Biodegr. 76, 24, 2013.

40. SONG M., LUO C., LI F., JIANG L., WANG Y., ZHANG D., ZHANG G. Anaerobic degradation of polychlorinated biphenyls (PCBs) and polychlorinated biphenyls ethers (PBDEs), and microbial community dynamics of electronic waste-contaminated soil. Sci Total Environ. 502C, 426, 2015.

41. DELMOTTEN., KNIEF C., CHAFFRON S., INNEREBNER G., ROSCHITZKI B., SCHLAPBACH R. Community proteogenomics reveals insights into the physiology of phyllosphere bacteria. PNAS. 106 (38), 16428, 2009.

42. KNIEF C., FRANCES L., VORHOLT J.A. Competitiveness of diverse methylobacterium strains in the phyllosphere of arabidopsis thaliana and identification of representative models, including M. extorquens PA1.Microbial Ecol. 60 (2), 440, 2010.

43. OTTESEN A.R., GORHAM S., REED E., NEWELL M.J., RAMACHANDRAN P., CANIDA T., ALLARD M., EVANS P., BROWN E., WHITE J.R. Using a Control to Better Understand Phyllosphere Microbiota. PLoS ONE. 11 (9), 2016. e0163482.

44. LI Y.F., JIA H.L. Prediction of gas/particle partition quotients of Polybrominated Diphenyl Ethers (PBDEs) in north temperate zone air: An empirical approach. Ecotox Environ Safe. 108 (108), 65, 2014.

45. HANG X., LI S., SU Y., BARRESI E., DEJONG M., HUNG H. Atmospheric concentrations of halogenated flame retardants at two remote locations: the canadian high arctic and the tibetan plateau. Environ Pollut. 161 (1), 154, 2012.

46. BESIS A., BOTSAROPOULOU E., VOUTSA D., SAMARA C. Particle-size distribution of polybrominated diphenyl ethers (PBDEs) in the urban agglomeration of Thessaloniki, northern Greece. Atmos Environ. 104, 176, 2015.

47. LAMMEL G., AUDY O., BESIS A., EFSTATHIOU C., ELEFTHERIADIS K., KOHOUTEK J., KUKUČKA P., MULDER M.D., PŘIBYLOVÁ P., PROKEŠ R., RUSINA T.P., SAMARA C., SOFUOGLU A., SOFUOGLU S.C., TAŞDEMIR Y., VASSILATOU V., VOUTSA D., VRANA B. Air and seawater pollution and air-sea gas exchange of persistent toxic substances in the Aegean Sea: spatial trends of PAHs, PCBs, OCPs and PBDEs. Environ. Sci. Pollut. Res. 22 (15), 11301, 2015.

48. VORHOLT J.A. Microbial life in the phyllosphere. Nat Rev Microbiol. 10 (12), 828, 2012.

49. YANG M., QI H., JIA H.L., REN N.Q., DING Y.S., MA W.L. Polybrominated diphenyl ethers in air across china: levels, compositions, and gas-particle partitioning. Environ Sci Technol. 47 (15), 8978, 2013.

50. LI Y., CHEN L., NGOC D.M., DUAN Y.-P., LU Z.B., WEN Z.H., MENG X.Z. Polybrominated Diphenyl Ethers (PBDEs) in $\mathrm{PM}_{2.5}, \mathrm{PM}_{10}$, TSP and Gas Phase in Office Environment in Shanghai, China: Occurrence and Human Exposure. PLoS ONE. 10 (3), 2015. e0119144. 